Int. J. Plant Sci. 180(2):128-140. 2019. (C) 2018 by The University of Chicago. All rights reserved. This work is licensed under a Creative Commons Attribution-NonCommercial 4.0 International License (CC BY-NC 4.0), which permits non-commercial reuse of the work with attribution. For commercial use, contact journalpermissions@press.uchicago.edu.

1058-5893/2019/18002-0002\$15.00 DOI: $10.1086 / 701103$

\title{
NEW MACROFOSSILS OF THE AUSTRALIAN CYCAD BOWENIA AND THEIR SIGNIFICANCE IN RECONSTRUCTING THE PAST MORPHOLOGICAL RANGE OF THE GENUS
}

\author{
Robert S. Hill, ${ }^{1, *}$ Kathryn E. Hill, ${ }^{*}$ Raymond J. Carpenter, ${ }^{*}+$ and Gregory J. Jordant \\ *School of Biological Sciences and the Environment Institute, University of Adelaide, South Australia 5005, Australia; and \\ tSchool of Biological Sciences, University of Tasmania, Private Bag 55, Hobart, Tasmania 7001, Australia
}

Editor: Michael T. Dunn

Premise of research. This study describes a new fossil species of Bowenia and reconsiders known fossil species and their evolutionary significance.

Methodology. The fossils we describe here were collected for this study or were available from previous collections made over several decades. The fossils were identified by direct comparisons with extant and fossil species.

Pivotal results. A reexamination of known and newly discovered Bowenia macrofossils confirms the presence of at least three fossil species in Australia. A new species, Bowenia johnsonii, is described from the southernmost location, the Early Eocene Lowana Road site in southwest Tasmania. When compared with the two extant species, the three fossil species demonstrate two distinct pinnule morphologies: relatively small with distinct serrations in Bowenia eocenica and Bowenia papillosa and larger pinnules with minute serrations in B. johnsonii. When considered together, the stomata of the extant species are denser and larger than those of the fossil taxa.

Conclusions. The cycad genus Bowenia has a restricted extant distribution along the east coast of Queensland but is known more widely within Australia from fossils. The fossil record of Bowenia is important in documenting the past distribution of this genus, and aspects of its pinnule morphology provide insights into its environmental interactions. The possible relationship of the fossil Bowenia species with the Aptian Argentinian genus Eobowenia is considered, along with some fragmentary Australian fossils of probable Bowenia.

Keywords: cycads, Zamiaceae, Bowenia, Eocene, Australia.

\section{Introduction}

Cycads comprise a small but important part of the living Australian flora, but the fossil record of the extant genera is relatively sparse (Hill 1998a). Bowenia is an endemic Australian cycad genus, restricted to two extant species, Bowenia spectabilis Hook. ex Hook.f. and B. serrulata (W. Bull.) Chamberlain, both of which are found in small areas of near-coastal Queensland in northeast Australia (fig. 1). Both species are lowstatured understory plants with a subterranean stem (Chamberlain 1912), but whereas B. spectabilis occurs in wet tropical rain forest, $B$. serrulata occurs in a more seasonally dry climate and is often found in eucalypt woodlands, most commonly near water bodies (Wilson 2004). The published fossil record of Bowenia consists of pinnule fragments from several Eocene sites in eastern and central Australia (fig. 1), including two named species, Bowenia eocenica R.S. Hill from Anglesea and Bowenia papillosa R.S. Hill from Nerriga (Hill 1978).

\footnotetext{
1 Author for correspondence; email: bob.hill@adelaide.edu.au.
}

Manuscript received July 2018; revised manuscript received September 2018; electronically published December 26, 2018.
Bowenia has a long history of uncertain familial placement within the cycads, having been variously assigned to Zamiaceae, Stangeriaceae, and the monotypic Boweniaceae, based on its comparative morphology. Several molecular phylogenies of cycads have been published (e.g., Treutlein and Wink 2002; Hill et al. 2003; Bogler and Francisco-Ortega 2004; Chaw et al. 2005; Zgurski et al. 2008; Salas-Leiva et al. 2013; Condamine et al. 2015), and the consistent finding is that only two families can be recognized with confidence, the Cycadaceae, containing the single genus Cycas, and the Zamiaceae, containing all other genera. Based on molecular evidence, Bowenia appears to be somewhat isolated from the other cycads, with a stem extending to the Cretaceous (Nagalingum et al. 2011; Salas-Leiva et al. 2013).

The purpose of this article is to reexamine the species originally published by Hill (1978) and specimens from several other localities that have not previously been examined in detail to determine what they reveal about the evolution of this highly distinctive genus and its place in the broader Australian vegetation. Furthermore, the preservation of most of the fossils allows a detailed examination of the pinnule and stomatal morphology and an assessment of the environments inhabited 


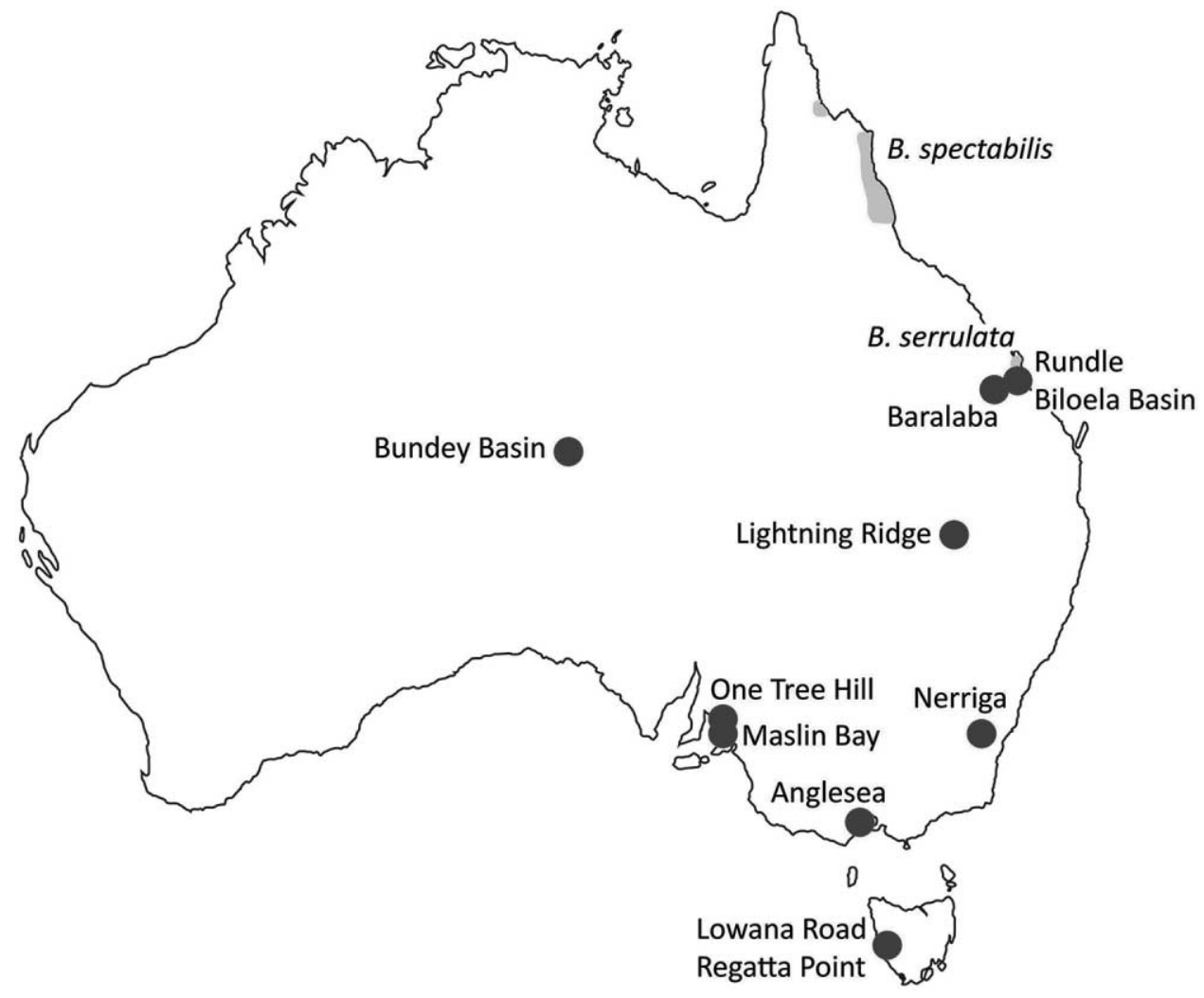

Fig. 1 Map of Australia, showing the distribution of the living Bowenia species (in gray) and the fossil localities considered in this study (in black). A color version of this figure is available online.

by these fossil species when they were alive. The recent description of Aptian fossils from Argentina assigned to Eobowenia (Coiro and Pott 2017) is also considered, since it is probably the most closely related fossil taxon to Bowenia.

\section{Material and Methods}

\section{Extant Specimens}

Bowenia serrulata occurs near Gladstone in Queensland and Bowenia spectabilis occurs in northeast Queensland in areas surrounding Cairns (fig. 1). Five B. spectabilis specimens were collected from Butchers Creek in the Atherton Tablelands in Queensland (lat. $17^{\circ} 32^{\prime} \mathrm{S}$, long. $145^{\circ} 69^{\prime} \mathrm{E}$ ) directly for this study, and 35 specimens of $B$. spectabilis and 13 of $B$. serrulata were provided by the Queensland Herbarium (BRI), National Herbarium of Victoria (MEL), and Australian Tropical Herbarium (QRS).

\section{Preparation of Cuticles of Extant Specimens}

Cuticles were prepared using standard techniques. Most often, $1-\mathrm{cm}^{2}$ pieces of pinnule were cut from the margin halfway along the lamina. Pinnule pieces were placed into test tubes and covered in $80 \%$ ethanol v/v overnight. The ethanol was then replaced with a $2: 1$ solution of $35 \% \mathrm{w} / \mathrm{v}$ hydrogen peroxide and $80 \%$ ethanol v/v and gently heated until the pinnule pieces turned translucent. The pinnule pieces were then rinsed with reverseosmosis (RO) water and placed under a dissecting microscope so that debris could be brushed away from the cuticle, which was then rinsed with $\mathrm{RO}$ water. Cuticles were then stained with crystal violet and mounted on slides in phenol glycerine jelly.

\section{Fossil Localities}

New material and previously described or reported specimens were available from several sites.

\section{Nerriga}

The Nerriga locality is about $90 \mathrm{~km}$ east-northeast of Canberra in the southern tablelands of New South Wales (fig. 1). The fossil-bearing sediments are considered to be about 45 Myr old, which is close to the Early-Middle Eocene boundary (table 1). The macrofossil flora at Nerriga has been described as representing simple notophyll vine forest (Christophel 1980) as defined by Webb (1959). It is dominated by angiosperms, with several species of large and broad-leaved Lauraceae (Hill 1986), in conjunction with a common largeleaved Menispermaceae species attributed to a vine (Hill 1989) and several other entire- or serrate-margined leaf taxa (Hill 1982), along with the tropical Casuarinaceae genus Gymnostoma (Christophel 1980). The extinct cycad genus Pterostoma 
Table 1

Location and Age of the Sites Containing the Macrofossil Specimens Considered in Detail

\begin{tabular}{|c|c|c|}
\hline Site and location & Age & References \\
\hline Estancia Bajo Grande (lat. $46^{\circ} 57^{\prime} \mathrm{S}$, long. $69^{\circ} 18^{\prime} \mathrm{W}$ ) & Aptian & Archangelsky 1966; Coiro and Pott 2017 \\
\hline Bundey Basin (lat. $22^{\circ} 39^{\prime} \mathrm{S}$, long. $135^{\circ} 15^{\prime} \mathrm{E}$ ) & Late Campanian-Maastrichtian & Carpenter et al. 2015 \\
\hline $\begin{array}{l}\text { Lowana Road/Regatta Point (lat. } 42^{\circ} 11^{\prime} \mathrm{S} \text {, } \\
\text { long. } 145^{\circ} 22^{\prime} \mathrm{E} \text { ) }\end{array}$ & Early Eocene & Carpenter et al. 2012 \\
\hline Nerriga (lat. $35^{\circ} 07^{\prime} \mathrm{S}$, long. $150^{\circ} 05^{\prime} \mathrm{E}$ ) & Early-Middle Eocene boundary & $\begin{array}{l}\text { Wellman and McDougal 1974; } \\
\text { Truswell and Owen } 1988\end{array}$ \\
\hline Maslin Bay (lat. $35^{\circ} 13^{\prime} \mathrm{S}$, long. $138^{\circ} 29^{\prime} \mathrm{E}$ ) & Early Middle Eocene & McGowran et al. 1970 \\
\hline Anglesea (lat. $38^{\circ} 25^{\prime} \mathrm{S}$, long. $\left.144^{\circ} 11^{\prime} \mathrm{E}\right)$ & Late Middle Eocene & Christophel et al. 1987 \\
\hline Rundle/Biloela Basin (lat. 2340'S, long. $151^{\circ} 10^{\prime} \mathrm{E}$ ) & Late Eocene & $\begin{array}{l}\text { Foster and Harris 1981; Rowett 1988; } \\
\text { Macphail et al. } 2014\end{array}$ \\
\hline Lightning Ridge (lat. $29^{\circ} 26^{\prime} \mathrm{S}$, long. $147^{\circ} 58^{\prime} \mathrm{E}$ ) & Latest Oligocene-mid-Late Miocene & Carpenter et al. 2011 \\
\hline Baralaba (lat. $24^{\circ} 11^{\prime} \mathrm{S}$, long. $149^{\circ} 49^{\prime} \mathrm{E}$ ) & Miocene & Wilson 2004 \\
\hline
\end{tabular}

has also been recorded at Nerriga, as well as a fossil species of the extant cycad genus Lepidozamia (Hill 1980).

\section{Anglesea}

The Anglesea coal mine is about $3 \mathrm{~km}$ northwest of the coastal town of Anglesea in Victoria (fig. 1), and the fossil-bearing sediments are considered to be of late Middle Eocene age (table 1). These sediments sit above the main coal seam as clay and clay sand lenses. The exact stratigraphic positions of the various lenses is unknown (Christophel et al. 1987). The macroflora at Anglesea is also dominated by angiosperms, but nonangiosperms include common fragments of the extinct cycad Pterostoma (Hill 1980) and several species and genera within the conifer family Podocarpaceae (Greenwood 1987; Hill and Scriven 1998). Angiosperm remains are very well preserved and diverse and include Gymnostoma (Casuarinaceae; Christophel 1980), Ebenaceae (Basinger and Christophel 1985), several Lauraceae species (Christophel et al. 1987), Proteaceae (Christophel 1984; Hill and Christophel 1988; Carpenter et al. 2016), Myrtaceae (Christophel and Lys 1986), and many other unidentified taxa. Christophel et al. (1987) regarded the Anglesea vegetation as being closest to extant Complex Mesophyll Vine Forest and considered that its composition and structure was similar to that of the vegetation at modern Noah Creek in northeast Queensland.

\section{Maslin Bay}

The Maslin Bay locality is also now near coastal, about $35 \mathrm{~km}$ south of Adelaide in South Australia (fig. 1). The fossils were preserved within a single carbonaceous clay lens in the North Maslin Sands (Christophel and Blackburn 1978) that are considered to have formed in the early Middle Eocene (table 1). The Maslin Bay macroflora is highly diverse and dominated by broad-leaved angiosperms (Christophel 1994). Rare ferns (Lygodium; Rozefelds et al. 1992) and conifers, including Agathis in the Araucariaceae (Christophel and Blackburn 1978) and Willungia in the Podocarpaceae (Hill and Pole 1992), have been recorded. Several broad-leaved angiosperm taxa have been identified, including extinct genera of the Proteaceae (Blackburn 1981; Carpenter et al. 2006, 2016), Ceratopetalum (Cunoniaceae; Barnes and Hill 1999), and a deciduous leaved Notho- fagus species (Nothofagaceae; Scriven et al. 1995). Many other taxa have been reported (e.g., Brachychiton, up to five Myrtaceae taxa, Ebenaceae, see Scriven 1993) but have not been formally described. Gymnostoma (Casuarinaceae) is also common (Christophel 1994). The flora as a whole has been compared with modern Complex Notophyll Vine Forest (Greenwood 1994).

\section{Rundle Formation and Biloela Basin Sediments}

The Rundle Oil Shale (Rundle Formation, Narrows Graben) occurs $\sim 25 \mathrm{~km}$ northwest of Gladstone in Queensland (fig. 1) and contains diverse but fragmented plant macrofossil remains (Rowett 1988), which are regarded as being most probably of Late Eocene age (table 1). The macroflora at Rundle is so far known only from dispersed cuticle, where diversity is high, angiosperms dominate, and Lauraceae is the prominent family (Christophel 1989).

New fossiliferous material from the Biloela Formation of the Biloela Basin west of Gladstone was collected for the current study from the Zillmere Exploration Data Centre of the Geological Survey of Queensland. This basin is proximal to the Narrows Graben, and the Rundle and Biloela Formation sediments discussed here are probably palynostratigraphically contemporaneous (table 1). New samples of dispersed cuticle were recovered from borehole GSQ Monto 5, which contains the type section of the Biloela Formation (Noon and Grimes in Noon 1982). Similar to the Rundle shale sediments, Lauraceae cuticles were abundant in Monto 5 (Macphail et al. 2014).

\section{Lowana Road}

The Lowana Road sediments are part of widespread and thick Early Eocene (table 1) sediments that occur in the Strahan region of Macquarie Harbour in southwest Tasmania (fig. 1). The Lowana Road fossil flora is a discrete assemblage within this general region and was derived from estuarine vegetation growing in a warm to hot and wet climate (Carpenter et al. 2012). A regional Early Eocene flora was reported by Pole (2007) from dispersed cuticular remains. Mangrove species (e.g., the southernmost record of the mangrove palm genus Nypa; Pole and Macphail 1996) occur widely, and the 
Lowana Road assemblage also includes an extinct seed fern (McLoughlin et al. 2008), Lygodium (Rozefelds et al. 2017), and probable rainforest angiosperms (Carpenter et al. 2007; Conran et al. 2009). Conifer fossils are diverse and common regionally, and they include representatives of the Araucariaceae (Bigwood and Hill 1985; Hill and Bigwood 1987; Hill 1990), Cupressaceae (Paull and Hill 2009), and Podocarpaceae (Wells and Hill 1989; Hill and Carpenter 1991).

Other specimens considered here relied on published information and not direct observation of specimens. All localities are listed in table 1.

\section{Fossil Specimens}

The fossil pinnules from Nerriga and Anglesea are mummified and could be retrieved more or less complete from the encasing sediments. This was done by soaking sediment blocks in dilute aqueous hydrogen peroxide that was gently heated to dissociate the sediments, which were then sieved to retrieve the macrofossils. Individual specimens were gently brushed clean and photographed using transmitted light to best show the venation patterns. The Lowana Road specimens were too fragmentary to be removed from the encasing sediments. Large blocks of sediment were split along bedding planes to reveal pinnule remains, often with the venation preserved as impressions in the sediment and with large pieces of the organic remains of the pinnules still attached. Sediment impressions were photographed using low-angle reflected light to best highlight the venation pattern and pinnule margins.

Cuticle slides of six Bowenia eocenica specimens from the Anglesea site were borrowed from Melbourne Museum. Cuticle slides of the Lowana Road specimens were prepared by soaking organic pinnule fragments in $5 \%$ aqueous chromium trioxide solution until all organic matter except the cuticle had dissolved. The cuticle was then rinsed in distilled water, cleared briefly in $2 \%$ aqueous ammonia solution, rinsed again, and stained with safranin $\mathrm{O}$. Cuticles were then mounted on microscope slides in phenol glycerine jelly. Some unstained cuticles were attached to aluminium stubs with double-sided adhesive and coated with a gold-carbon mix. They were examined with an XL30 scanning electron microscope (Philips, Amsterdam) operated at $10 \mathrm{kV}$.

Rundle and Maslin Bay specimens consisted of dispersed cuticle only and were available from existing collections that formed the basis of detailed studies by Rowett (1988) and Scriven (1993), respectively. The cuticle slides form part of the David T. Blackburn Palaeobotany Collection at the University of Adelaide. Cuticles were rephotographed using an Olympus AX70 compound microscope fitted with an Olympus UC50 digital camera. Fragments of Bowenia cuticle from the Biloela Basin were recovered by sieving from associated sediments and prepared as for the Lowana Road cuticles.

The holotype, and only specimen of B. papillosa, was retrieved from the South Australian State Herbarium, where it is stored. Unfortunately, the accompanying cuticle slide could not be located, so a new cuticle slide was prepared from the remaining pinnule fragments. Observations made here came from this new slide, the existing published images, and some extra photographs that were not published in the original article (Hill 1978).

\section{Results}

\section{Fossil Identification}

The pinnule fossils from Nerriga and Anglesea have previously been described as species of Bowenia (Hill 1978). Bowenia pinnules have very distinctive serrate or entire margins and simple dichotomously branching venation without anastomoses. When serrations are present, they are the termination point for veins; in entire-margined pinnules, veins terminate at the margin without forming a serration. Thomas and Bancroft (1913) noted that Bowenia pinnules are amphistomatic but with significantly fewer stomata on the adaxial surface. They also recorded the guard cells as being situated practically at the level of the epidermis and less sunken than in any other cycad genus except Stangeria. Pant and Nautiyal (1963) added to this description by noting that rounded or oval hair scars are usually present above and between the veins on the abaxial surface and along the pinnule margins. According to Greguss (1968), Bowenia can be readily distinguished from other extant cycad genera because it has stomata scattered on the upper pinnule surface (25 stomata $\mathrm{mm}^{-2}$ ) and grouped in bands on the lower surface (55-60 stomata $\mathrm{mm}^{-2}$ ). Also, in comparison with other cycads, the epidermal cell walls are mostly thin.

Given the combination of characters listed above, assigning a fossil to Bowenia should be relatively straightforward, provided a pinnule or a significant fragment of one is preserved and cuticle morphology is well preserved. This is the case for fossils from Nerriga, Anglesea, and Lowana Road. The fossils from Maslin Bay, Rundle, and the Biloela Basin consist of dispersed cuticle only. The Rundle dispersed cuticle fragments are quite common and include some with margins attached and serrations sometimes present. A combination of the cuticular morphology, presence of serrations, and veins that terminate in them mean that these fossils can be assigned to Bowenia with confidence. The Maslin Bay taxon is represented by rare fragments of dispersed cuticle. While this cuticle is consistent with Bowenia, no pinnule margins have been recovered and assignment to the genus is less certain. However, the cuticular morphology of this taxon is consistent with Bowenia and matches no other extant cycad. The same justification applies for the Biloela Basin specimens. The generic identification of these specimens has been complicated by the recent description of the fossil cycad genus Eobowenia by Coiro and Pott (2017). The significance of this genus is considered in detail later.

\section{Reconsideration of the Previously Described Species}

\section{Bowenia papillosa}

Hill (1978) described B. papillosa from the basal half of a single pinnule and the rachis to which it was attached. This exceptionally well-preserved fossil was assigned to a new species of Bowenia because of the presence of unicellular papillae, which occur over the veins, more commonly on the upper than on the lower pinnule surface. The other notable feature of this fossil is the clear preservation of numerous dichotomously branching veinlets arising from the veins. In reconsidering this specimen, it was noted that in the original illustra- 
tion of the specimen (fig. 2 in Hill 1978) the pinnule and rachis, which were separated from each other during recovery of the fossil from the sediment, were almost certainly illustrated the wrong way around. In all living Bowenia specimens examined, the lateral pinnules are asymmetrical, with the more convex margin being on the apical side of the whole leaf. The B. papillosa specimen illustrated by Hill (1978) has the convex side presented toward the base. That has been corrected in the illustration of this specimen here (fig. 2B). This specimen is smaller than pinnules of either of the extant species (table 2; fig. 2A), although some Bowenia serrulata pinnules overlap this size range. Bowenia papillosa also has distinctly smaller and less dense stomata than either of the extant species (table 2).

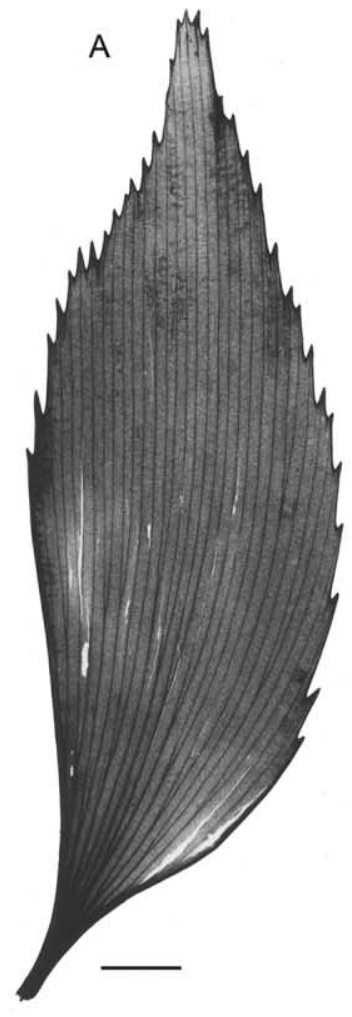

B

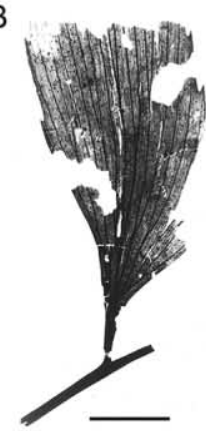

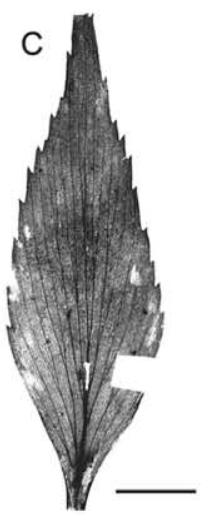
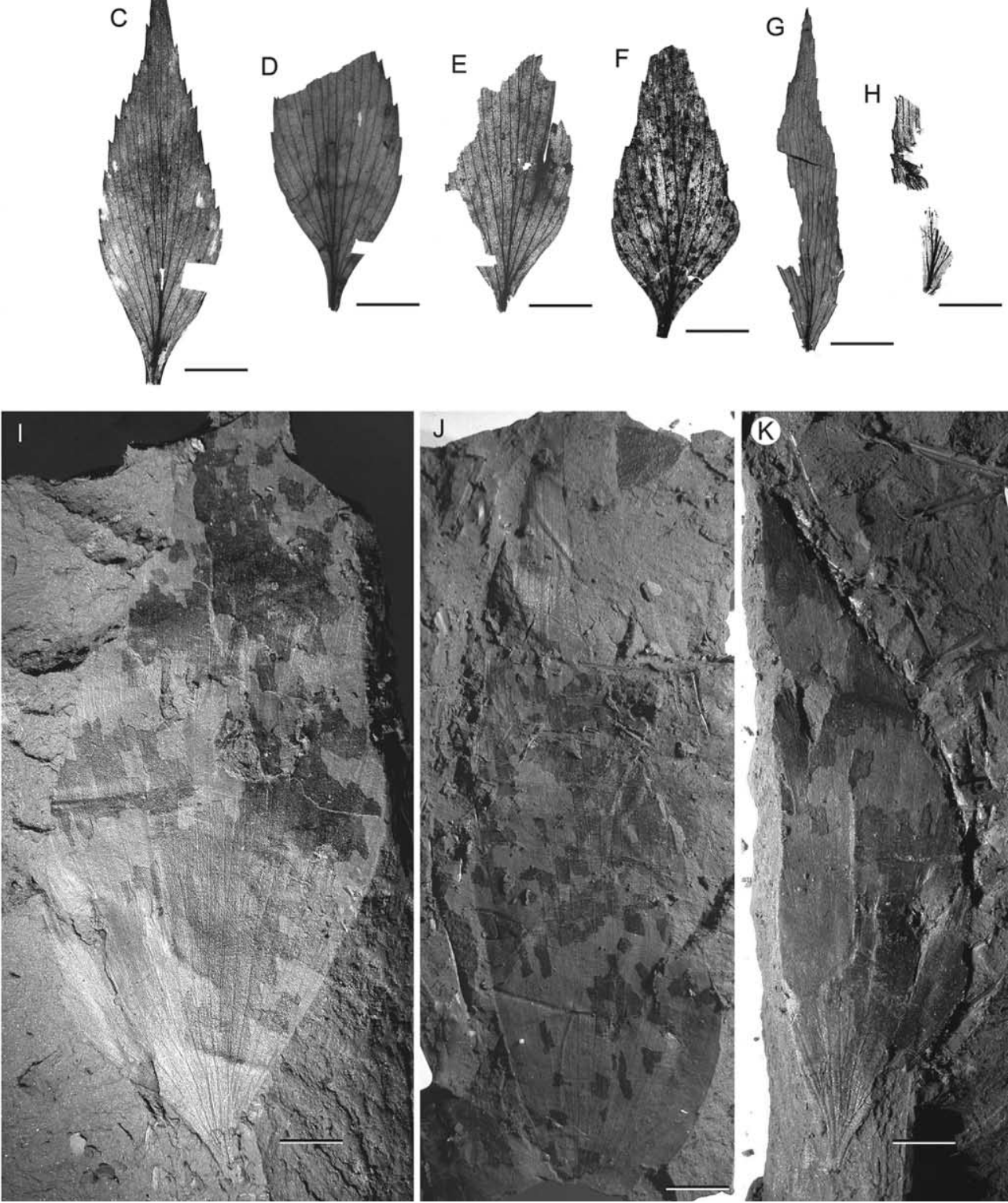

Fig. 2 Pinnules of extant and fossil Bowenia. A, Bowenia serrulata, cleared pinnule of the extant species, showing the serrate margin and dichotomously branching veins that all arise from the pinnule base. All veins terminate in serrations. B, Holotype and only specimen of Bowenia papillosa from Nerriga (N-0114), with the basal half of a single pinnule preserved. The attachment of the pinnule to the rachis is in the opposite direction to that figured in Hill (1978) and more likely reflects the orientation of the pinnule. Venation is very similar to that of B. serrulata, with veins terminating in serrations. $C-H$, Specimens of Bowenia eocenica from Anglesea $(C=\mathrm{AN} 2293, D=\mathrm{ANb} 3000, E=\mathrm{AN} 2167, F=2172 /$ 2094, $G=$ ANb3001, $H=$ P52689a). The venation is very similar to B. serrulata, except that in each specimen there is a rudimentary midvein at the base of the pinnule that extends for up to one-quarter of the length of the pinnule. Veins terminate in serrations. $H$ is the holotype of this species. $I-K$, Specimens of Bowenia johnsonii from Lowana Road, including the holotype $I(I=\mathrm{LO}-4, J=\mathrm{LO}-5, K=\mathrm{LO}-7)$. Venation is very similar to $B$. serrulata, with veins terminating in very small serrations. Scale bars $=0.5 \mathrm{~cm}$. 
Table 2

Mean Pinnule Size and Stomatal Traits $( \pm$ SD) of All Bowenia Species Considered

\begin{tabular}{lcccc}
\hline Species & Pinnule area $\left(\mathrm{mm}^{2}\right)$ & \multicolumn{1}{c}{ Serrations } & Stomatal density, abaxial surface $\left(\right.$ stomata $\left.\mathrm{mm}^{-2}\right)$ & Stomatal size $\left(\mu \mathrm{m}^{2}\right)$ \\
\hline B. eocenica & $137 \pm 60$ & Intermediate & $35 \pm 4$ & $1246 \pm 187$ \\
B. papillosa & 263 & Intermediate & $29 \pm 5$ & $1390 \pm 83$ \\
B. johnsonii & $1061 \pm 240$ & Small & $35 \pm 11$ & $1503 \pm 286$ \\
Maslin Bay & Unknown & Unknown & $41 \pm 2$ & $1588 \pm 154$ \\
Rundle & Unknown & Intermediate-large & $44 \pm 4$ & $1422 \pm 103$ \\
Bundey Basin & Unknown & Unknown & Unknown & $1232 \pm 233$ \\
B. serrulata & $1772 \pm 1129$ & Large & $48 \pm 10$ & $2010 \pm 321$ \\
B. spectabilis & $2567 \pm 873$ & Absent or small & $48 \pm 16$ & $2003 \pm 338$ \\
Eobowenia incrassata & $32 \pm 2$ & Disorganized & Unknown & $1045 \pm 203$ \\
\hline
\end{tabular}

Note. Where the species name is uncertain, the fossil location is listed.

\section{Bowenia eocenica}

Bowenia eocenica was described from two small fragments of what was probably a single pinnule retrieved from the Anglesea sediments (Hill 1978). While these fragments are small, they preserve important parts of the pinnule, since one demonstrates that the margin is regularly serrate and the other shows what appears to be a rudimentary midvein at the base of the pinnule (fig. $2 \mathrm{H}$ ), a feature otherwise not seen in the genus. The cuticle lacks the papillae of $B$. papillosa and this, along with the presence of the rudimentary midvein, justified its placement in a separate species. Since the publication of this species in 1978, thousands of mummified leaves, mostly angiosperms, have been collected from the Anglesea sediments and most are now housed at Melbourne Museum. Several nearly complete specimens of fossil Bowenia pinnules were retrieved during this process and available for this study.

With complete pinnules available, there are important features that can be considered in more detail. First, since all of these pinnules have a rudimentary midvein at the base of the pinnule, they belong to $B$. eocenica (fig. $2 \mathrm{C}-2 \mathrm{H}$ cf. fig. $2 \mathrm{~A}$ ). Second, it is clear that the pinnules of B. eocenica from Anglesea are smaller (in length, width, and area) than those of either of the extant species (table 2), although as with $B$. papillosa, there was some overlap with $B$. serrulata.

An examination of the cuticular morphology of new specimens of B. eocenica from Anglesea confirms the details of the original description. However, several trichome bases were observed, and in some cases what appears to be a basal cell of the trichome is also preserved (fig. 3A). These structures are different than the papillae described for B. papillosa. Bowenia eocenica has significantly smaller stomata than either of the extant species and also fewer per unit area (table 2).

\section{Specimens from New Locations}

\section{Lowana Road}

The Early Eocene Lowana Road sediments (fig. 1) have yielded a large number of complete and fragmentary pinnules (fig. 2I$2 K)$. These pinnules are larger than those of the specimens from Nerriga and Anglesea, but on average they are smaller than either of the extant species, although they overlap the size range of both (table 2). They consistently lack a midvein, which separates them from $B$. eocenica, and no papillae have been ob- served, which separates them from $B$. papillosa. They have the typical Bowenia stomatal morphology (fig. 3B). Rare trichome bases are preserved, but there is no evidence of the basal trichome cell that was present in some B. eocenica specimens. The scanning electron micrographs of this species show the very thin cuticle, including that around the stomata (fig. 3C, 3D). However, some epidermal cells have much thicker cuticle, which shows as a darker stained cell in the light micrographs (fig. 3B). An important feature of these pinnules is the size and shape of the serrations. While they are clearly present, they are relatively small and represent rounded indentations rather than the obvious and relatively large teeth of extant $B$. serrulata (fig. $4 D$ cf. fig. 4A) or those of the two fossil species, B. eocenica and B. papillosa (fig. 4B, 4C). Some specimens of extant Bowenia spectabilis have serrations that are virtually identical to those of the Lowana Road specimens (fig. $4 D$ cf. fig. $4 E$ ). This means that either the fossils represent $B$. spectabilis, or a new species should be established in recognition of the large spatial and temporal separations of fossil and extant specimens and the possibility that reproductive or other vegetative characters may have been distinct. We favor the latter option, given that all the fossil specimens examined are serrate, whereas serrate pinnules are rare in B. spectabilis (Johnson 1959; Wilson 2004), and the Lowana Road fossils have significantly smaller and less dense stomata than either of the extant species (table 2) and larger pinnules than $B$. serrulata. Therefore, we place the Lowana Road fossils in a new species of Bowenia, here named B. johnsonii.

\section{Rundle/Biloela Basin}

Dispersed cuticle fragments from the probable Late Eocene sediments at Rundle in Queensland (fig. 1) were identified as Bowenia by Rowett (1988). Rowett (1988) considered that papillae occur on at least some of the specimens, especially on the upper surface, and he hence assigned these specimens to $B . p a-$ pillosa. We had access to some but not all of Rowett's dispersed cuticle slides and new cuticle specimens of Bowenia from the Biloela Basin, which probably belong to the same taxon. Some possible papillae bases were observed (fig. $3 E$, although these may more plausibly be trichome bases without the basal cell preserved), as were trichome bases with the basal trichome cell in place (fig. $3 F$ ). This suggests an affinity with B. papillosa, but more complete specimens may lead to a different conclusion. Some specimens included fragments of the pinnule margin, confirming the presence of well-developed serrations at 

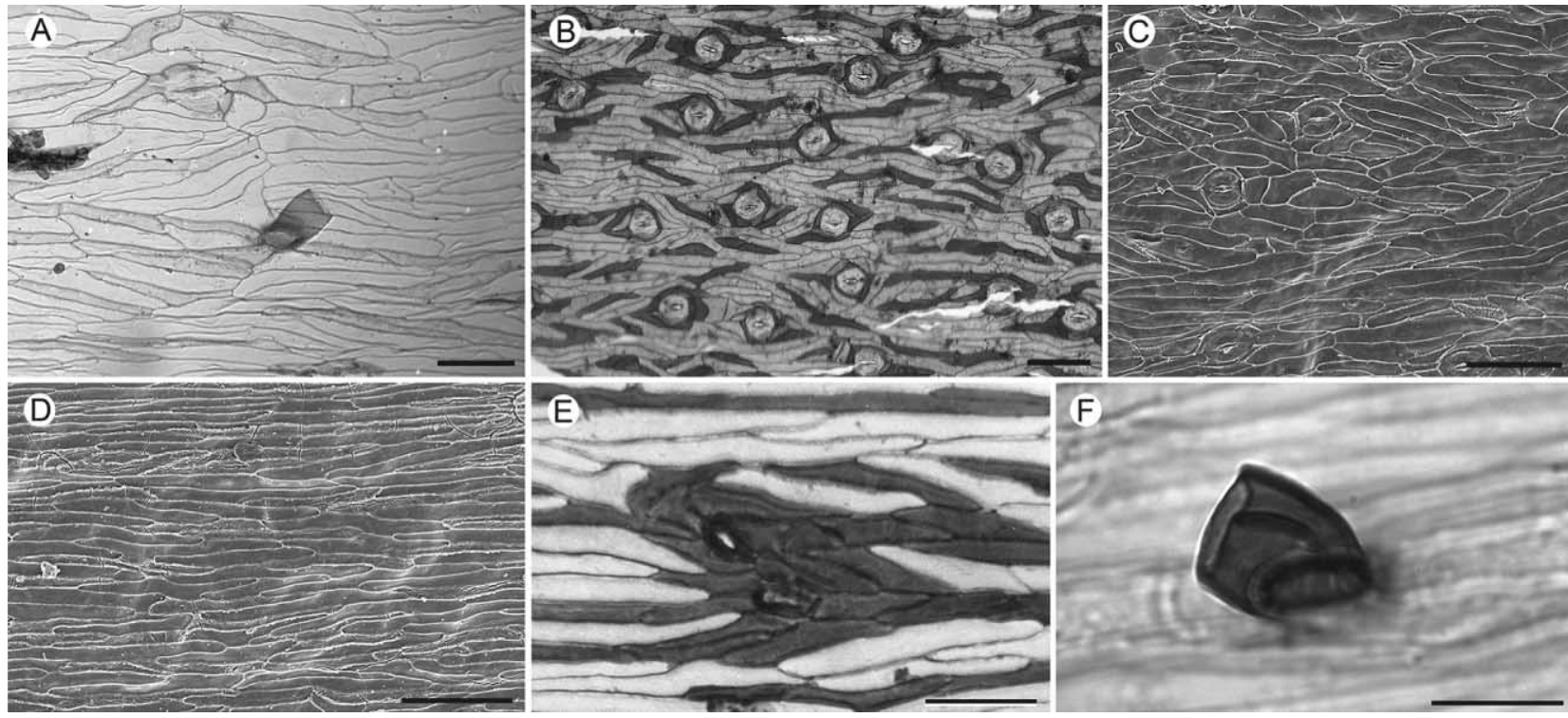

Fig. 3 Light micrographs (LMs) and scanning electron micrographs (SEMs) of fossil Bowenia cuticles. A, LM of the adaxial pinnule surface of Bowenia eocenica from Anglesea, showing a trichome base with a cylindrical basal trichome cell (AN2094); scale bar $=120 \mu \mathrm{m}$. $B, \mathrm{LM}$ of the abaxial pinnule surface of Bowenia johnsonii from Lowana Road, showing stomata among characteristic cycad epidermal cells (LO-5). Note the darker staining epidermal cells, indicating thicker cuticle over those cells; scale bar $=100 \mu \mathrm{m}$. C, SEM of the abaxial pinnule surface of B. johnsonii from Lowana Road, showing the inner cuticular surface, with characteristic cycad stomata (LO-4). The cuticle has cracked over some cells where it is thicker, a state represented by the darker staining cells in the LMs; scale bar $=100 \mu \mathrm{m}$. $D$, SEM of the adaxial pinnule surface of $B$. johnsonii from Lowana Road, showing the inner cuticular surface, with characteristic cycad epidermal cells (LO-5). Note the cracking of the cuticle over cells where the cuticle is thicker, as in C; scale bar $=100 \mu \mathrm{m}$. E, LM of the adaxial pinnule surface of Bowenia from Rundle, showing two possible papillae surrounded by dark staining cells (R-007); scale bar $=50 \mu \mathrm{m}$. F, LM of the adaxial pinnule surface of Bowenia from Biloela Basin, showing a trichome base with a cylindrical basal trichome cell (R-005); scale bar $=25 \mu \mathrm{m}$.

least $2 \mathrm{~mm}$ long, similar to those seen in B. serrulata, and much larger than those in the single specimen of $B$. papillosa (fig. $4 F$ cf. fig. $4 A, 4 B)$. Further specimens may show that this taxon is distinct from B. papillosa in having much larger serrations, possibly within the range of the extant species. Hence, these fragmentary specimens, while distinct from Eobowenia and clearly belonging to Bowenia, will not be assigned to a species until more complete specimens are obtained.

\section{Maslin Bay}

Dispersed cuticle fragments from the Middle Eocene Maslin Bay sediments were assigned to Bowenia by Scriven (1993). Her slides were available to us, and we found a small number of fragmentary specimens consistent with Bowenia. However, no trichome bases or papillae were observed and no margin is preserved, so these specimens remain identified at the generic level only, and even that is not certain given the cuticular morphology of Eobowenia (see "Discussion").

\section{Other Specimens}

Four other possible records of Bowenia deserve brief consideration. Carpenter et al. (2015) described a Late CampanianMaastrichtian flora from the Bundey Basin, which is $~ 140 \mathrm{~km}$ northeast of Alice Springs in the Northern Territory (fig. 1). The diverse dispersed cuticle macroflora described includes one specimen (their Fig. 7F) that they described as "?Bowenia." This cuticle fragment contains several stomata and is completely consistent with extant Bowenia, but they are also very similar to Eobowenia. The stomatal size of this specimen is close to that of all fossil Bowenia species (table 2). This represents the oldest known fossil record of the Bowenia lineage in Australia, but the fragmentary nature of the cuticle precludes it being assigned to a species. Hill (1998b) reported Bowenia from the Regatta Point site near Strahan in southwestern Tasmania (fig. 1), and Pole (2007) assigned dispersed cuticle specimens from sediments in the region to B. eocenica, despite the diagnosis for that species requiring details of pinnule morphology (Hill 1978). Here we regard all these fossils as probably belonging to $B$. johnsonii, noting that Early Eocene sediments are widespread in the Strahan region and that there appear to be many other fossil taxa in common between the Lowana Road assemblage and Regatta Point. Rowett (1998) recorded dispersed cuticle of Bowenia from the early Middle Eocene North Maslin Sands at One Tree Hill in South Australia (fig. 1). While this taxon was not illustrated, it may have been conspecific with the specimens recorded from the contemporaneous and geographically proximal Maslin Bay locality (see above). Carpenter et al. (2011) described a single specimen from the possibly latest Oligocene to mid-Late Miocene sediments at Lightning Ridge (fig. 1) as "?Bowenia," stating that the specimen "could be interpreted as the base of an apparently robust pinna fragment showing stout, occasionally dichotomising veins arising from a constricted base and lacking a midvein." 

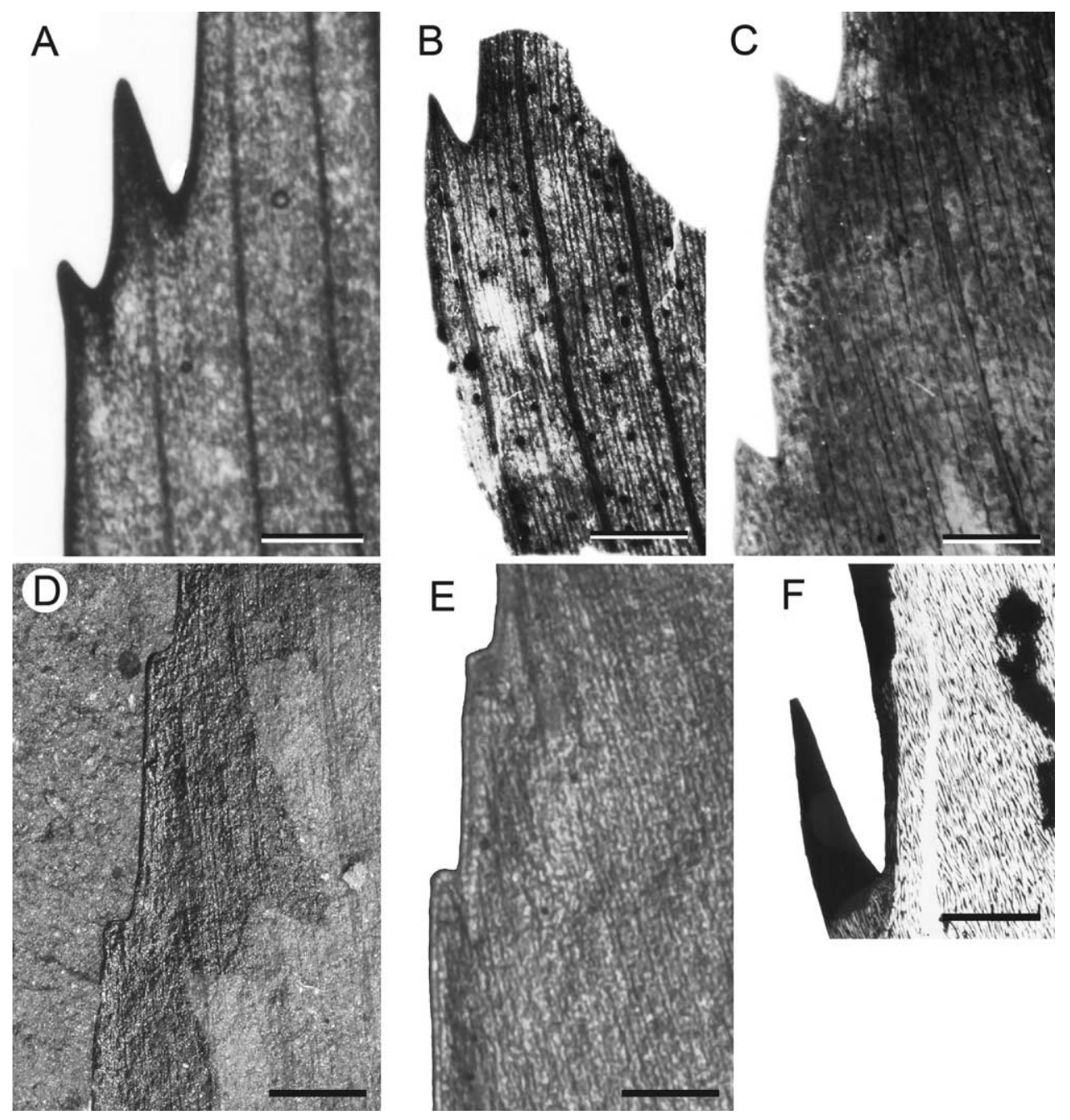

Fig. 4 Details of the margin of fossil and living Bowenia species. A, Bowenia serrulata, showing well-developed serrations with a vein terminating in each. $B$, Bowenia papillosa from Nerriga (N-0114), showing a well-developed serration, which is smaller than most of those of $B$. serrulata, but approximately in proportion to the difference in pinnule size. C, Bowenia eocenica (AN2293), showing well-developed serrations that are similar in size to those of B. papillosa. D, Bowenia johnsonii (LO-5), showing very small and rounded serrations that are quite distinct from all the other fossil species. E, Bowenia spectabilis, a rare specimen with serrations that are small and rounded and almost identical to those of B. johnsonii. F, Bowenia from Rundle (after Rowett 1988). Note the relatively large size of this serration, which is very similar to those of B. serrulata. Scale bars $=1 \mathrm{~mm}$.

This specimen is very similar to both fossil and extant pinnules of Bowenia in its size, shape, and venation, and is very likely to represent a fossil occurrence of the genus, but the lack of cuticle preservation and of a margin to the pinnule precludes a definite identification. Finally, Wilson (2004) noted a Miocene occurrence of Bowenia at Baralaba in central Queensland (fig. 1), but in the absence of illustrations or any other confirmation of the record, this is not considered further here.

\section{The Significance of Eobowenia}

Coiro and Pott (2017) described the new fossil genus, Eobowenia, from the Aptian locality at Estancia Bajo Grande, Santa Cruz Province, Argentina. The cuticle morphology of Eobowenia is very similar to extant Bowenia, and in the absence of sufficiently complete and well-preserved pinnules of the former, it may be impossible to separate the two genera. The single species of Eobowenia, Eobowenia incrassata, is described as having pinnate leaves with leaflets subopposite and with a broad base and serrate margins. A delicate midvein is reported, but the evidence for this is sparse (fig. $5 A, 5 B$ ).

The specimen illustrated by Coiro and Pott (2017; fig. 5B) is listed as the epitype, and they did not illustrate the holotype, which was originally described as Almargemia incrassata by Archangelsky (1966). The illustration in Archangelsky's article is not high quality by today's standards, but we were able to source a high-quality image of the holotype courtesy of S. Archangelsky and L. C. A. Martínez (fig. 5A). Artabe and Stevenson (1999) also illustrated this species (their fig. 2C, reinterpreted here as fig. $5 \mathrm{C}$ ), and while there is no scale bar, the specimen is 

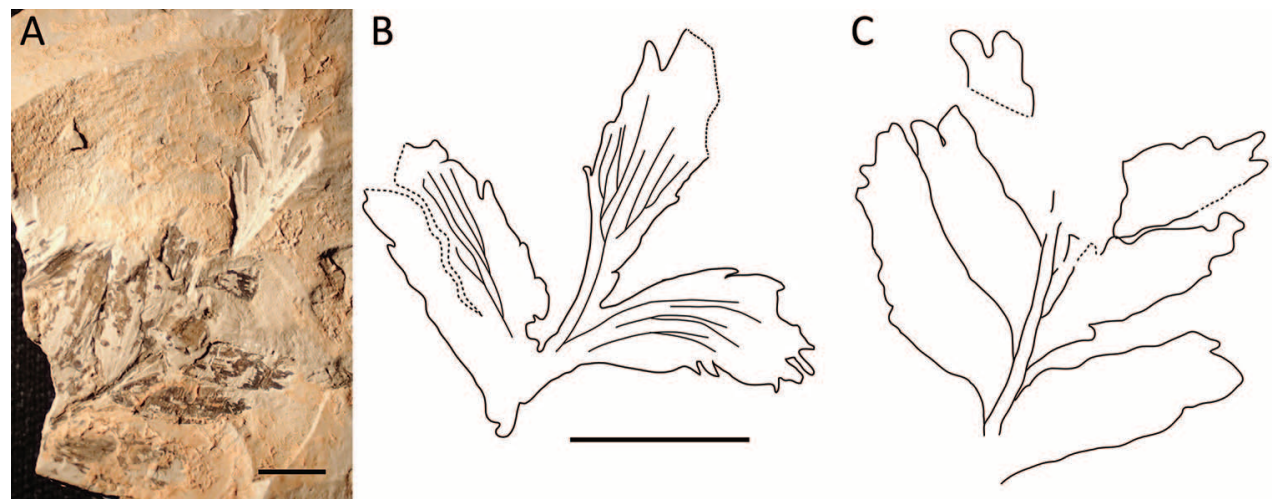

Fig. 5 Illustrations of Eobowenia incrassata. A, Holotype, showing the apex of the leaf (top right), with a poorly defined and lobed terminal pinna and with several pinnae arising from the main leaf axis below this. The attachment of each pinna is broad but is considerably narrower than the widest part of the pinna. These pinnae appear to have poorly defined lobes or teeth; scale bar $=5 \mathrm{~mm}$. $B$, Drawing of the isotype of E. incrassata, showing some of the poorly preserved veins. There may be evidence of a midvein here, but it is not compelling. Redrawn from Coiro and Pott (2017); scale bar $=5 \mathrm{~mm}$. C, Drawing of part of a leaf of E. incrassata, showing the middle portion of the leaf, with relatively well-defined pinnae that have broad attachments at the base, probably broader than that observed in the holotype. This specimen is redrawn from Artabe and Stevenson (1999). No scale bar was provided, and the original of this specimen has not been located. It is shown here with an estimated size based on $5 B$, but this is probably at the lower end of the potential size range.

informative in appearing to represent pinnae from the middle of a leaf.

It is possible that E. incrassata has a close relationship with Bowenia (Coiro and Pott 2017), but if so, some significant changes in leaf morphology in Bowenia took place in the $\sim 65 \mathrm{Myr}$ prior to the Early Eocene. However, it is clear that if fossils are found with cuticular morphology preserved, but with little detail of the whole pinna, then these fossils probably cannot be assigned with certainty to either Eobowenia or Bowenia.

\section{Systematics}

\section{Order-Cycadales E. Pfitzer. Ubersicht der Naturlichen Systems der Pflanzen. 28. 1898.}

Family-Zamiaceae P.F. Horaninow. Prima Lineae Systemis Naturae. Sty. Petersburg. 1834.

Genus-Bowenia Hook. ex Hook.f.

Species-Bowenia johnsonii R.S.Hill, K.E.Hill, Carpenter et Jordan sp. nov. (Figs. 2L-2K, 3B-3D, 4D)

Diagnosis. Bowenia fossils without evidence of reproductive structures. Pinnules 94 (77-104) mm long, 29 (21-34) mm wide, midvein absent, veins terminating in small rounded teeth. Trichome bases rare on epidermis, papillae absent.

Etymology. Named in memory of Dr. L.A.S. Johnson, who wrote the seminal work on Australian cycads.

Holotype. LO-4, stored at the School of Biological Sciences, University of Tasmania.

Repository. School of Biological Sciences, University of Tasmania.

Type locality. Lowana Road, southwestern Tasmania (lat. $42^{\circ} 11^{\prime} \mathrm{S}$, long. $145^{\circ} 22^{\prime} \mathrm{E}$ ).

\section{Comparison of Fossil and Living Species}

Of the two extant species, Bowenia spectabilis has the largest pinnules, and these are usually entire-margined, except for occasional specimens in more open vegetation that bear small, or sometimes large, serrations (Wilson 2004). Bowenia serrulata has, on average, significantly smaller pinnules than B. spectabilis (table 2) and consistently much more prominent serrations, and it also occurs in more open vegetation and in a generally warmer and drier climate than B. spectabilis (Wilson 2004). Two of the fossil species, $B$. eocenica and $B$. papillosa, have small pinnules with serrations of intermediate size and low stomatal density and size compared with the other fossil and extant species (table 2). Bowenia johnsonii has significantly larger pinnules than $B$. eocenica but has smaller serrations and a low stomatal density and size that are similar to B. eocenica and B. papillosa.

The common trichome type in Bowenia is typical of cycads in having a thickened complex base and a basal trichome cell that is cylindrical and terminates presumably where another trichome cell was once attached (fig. $3 A, 3 F$ ). This trichome structure is common in the Zamiaceae (Stevenson 1981) and has been illustrated by, for example, Acuña-Castillo and MarínMéndez (2013) from Zamia (now Chigua) restrepoi. The papillae in B. papillosa have not been recorded in other cycads.

One of the most distinctive features of the fossil Bowenia species is the rudimentary midvein in B. eocenica. Hill (1978) noted this feature in the pinnule fragment he described, stating that the "dichotomously branching veins arise alternately at the base of the pinnule over a greater distance than in the other species and the central vein gives the appearance of a midvein." This rudimentary midvein occurs in every $B$. eocenica pinnule (fig. $2 \mathrm{C}-2 \mathrm{H}$ ) but is absent from all other fossil and living Bowenia species examined. Midveins are a striking feature of Cycas species, but they also occur in some Zamiaceae species. Stevenson et al. (1996) concluded that there are two types of 
midvein in cycads: "a simple mid-vein composed of a single vein (e.g., Cycas) and a compound mid-vein composed of two or more veins (e.g., Stangeria)." They also noted the presence of compound midveins in the extant genus Chigua, and perhaps the closest to the situation seen in B. eocenica among the extant Zamiaceae species is in Chigua restrepoi (Stevenson 1990; fig. 6A). In this species a clearly defined midvein extends for about two-thirds of the length of the pinnule, with side branches occurring at high angles, sometimes branching dichotomously, before every vein ends in a serration. This venation pattern is very similar to that of B. eocenica, except that in the latter the midvein extends only about one-quarter of the length of the pinnule before disappearing among high-angle dichotomously branching veins that all terminate in serrations (fig. 6B). Bowenia eocenica is intermediate between the pattern seen in C. restrepo $i$ and $B$. serrulata (fig. $6 B$ cf. fig. 6A, 6C). Part of a fossil pinnule that has very similar venation to C. restrepoi, but with an even more robust midvein, has been recovered from Early Cretaceous sediments in Patagonia (Passalia et al. 2010; fig. 6D), showing that a strong midvein in pinnules was present in Gondwanan cycads long before B. eocenica was growing in southeastern Australia. As noted above, Eobowenia incrassata is described as having a delicate midvein (Coiro and Pott 2017), but the evidence for this is not compelling (fig. $5 B$ ) and is well short of the midvein in $B$. eocenica. We do not have enough evidence at present to know whether B. eocenica represents a link to a Bowenia ancestor that had pinnules with a midvein that was lost over time or whether it represents an isolated instance of developing a midvein that did not persist through to the present. It is important to note that because Bowenia is the only extant cycad with bipinnately compound leaves, the rachis bearing the pinnule is therefore probably equivalent to a pinna midvein (Stevenson
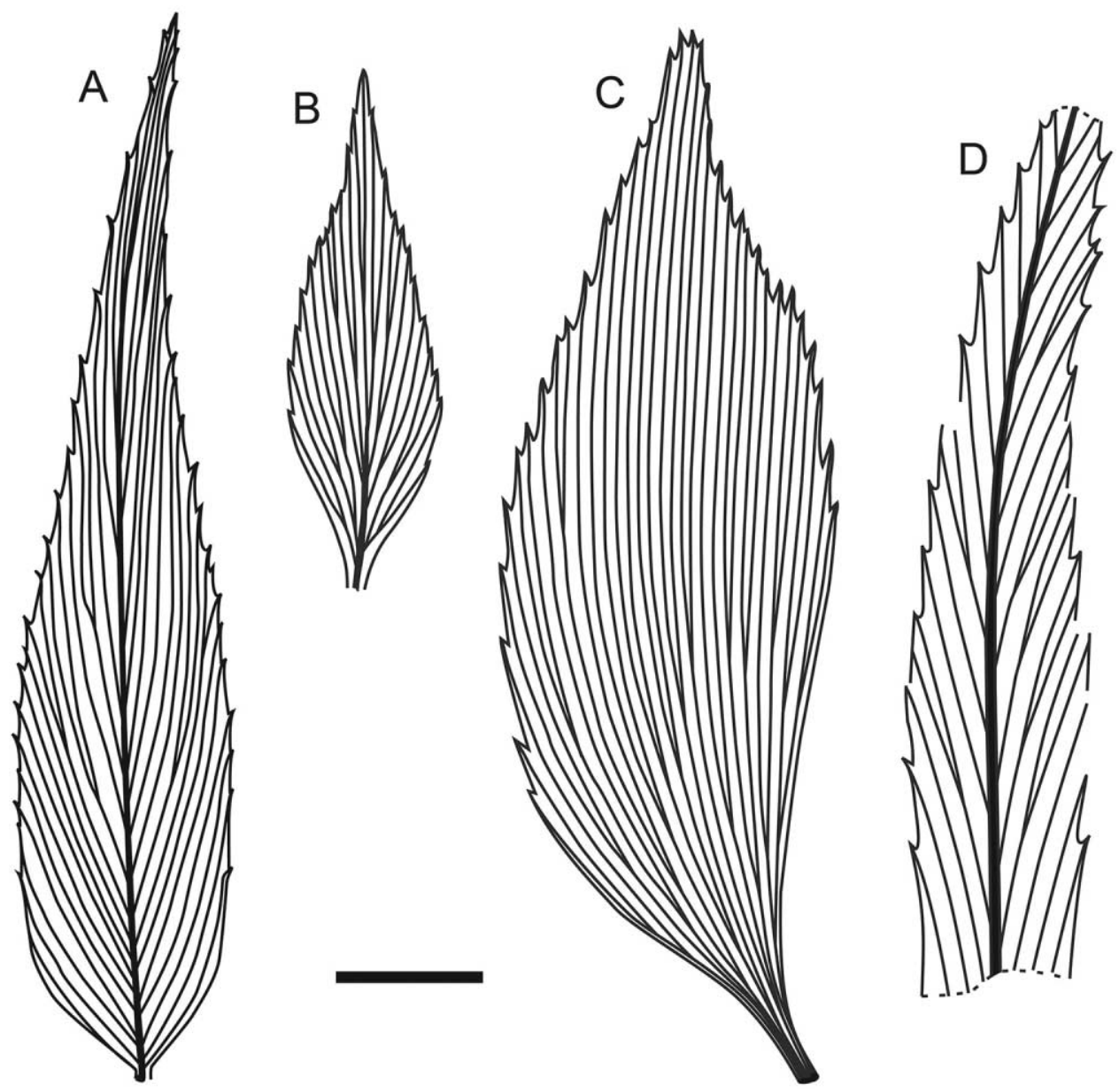

Fig. 6 Line drawings of the venation of pinnules of selected fossil and living cycads. A, Extant Chigua restrepoi (modified from Stevenson et al. 1996; Uzunova et al. 2001). Note the midvein that runs for about two-thirds of the length of the pinnule and the high-angle dichotomously branching veins that arise from it and terminate in serrations. B, Fossil Bowenia eocenica (AN2293). Note the rudimentary midvein that runs for about one-quarter of the length of the pinnule and the high-angle dichotomously branching veins that arise from it and terminate in serrations. $C$, Extant Bowenia serrulata. Note the lack of any midvein and the dichotomously branching veins that terminate in serrations. D, Fossil Restrepophyllum chiguoides (modified from Passalia et al. 2010). Note the well-developed midvein and the high-angle dichotomously branching veins that arise from it and terminate in serrations. Scale bar $=2 \mathrm{~cm}$ for $A, 1 \mathrm{~cm}$ for $B-D$. 
et al. 1996), and hence the comparison of venation patterns of B. eocenica with C. restrepo $i$ is, in fact, a comparison between a pinnule and a pinna.

\section{Discussion}

Three fossil species of Bowenia are now recorded: Bowenia papillosa, Bowenia eocenica, and the newly described Bowenia johnsonii, as well as several other specimens that may represent these or different species or perhaps even the genus Eobowenia. The locations of fossil Bowenia demonstrate that the genus must have been common across at least southeastern Australia and north into Queensland along the eastern Australian coast when Australia was still connected to Antarctica. Given the northward movement of Australia following its separation from Antarctica at about $43 \mathrm{Ma}$ (Cande et al. 2000; Sandiford and Quigley 2009), we can conclude that Bowenia once extended at least 35 degrees farther south than its current subtropical to tropical distributions. Extant Bowenia plants grow close to the ground, and both the leaves and pinnules do not have a clean abscission point; hence, they are inherently unlikely to provide vegetative material into fossil deposits, so these fossil occurrences suggest that Bowenia was probably quite common at all sites and particularly so at Lowana Road and possibly Anglesea.

The pinnules of the fossil Bowenia species are distinctive, with two species, B. eocenica and B. papillosa, having relatively small pinnules with clearly serrate margins, while $B$. johnsonii has larger pinnules with very small rounded serrations. The fossil species as a group has significantly lower stomatal density and size than the living species, indicating that the relative pinnule area allocated to stomata has increased since the Eocene. Hill $(1978,1998 b)$ considered entire-margined pinnules to be the probable ancestral state in Bowenia, but a combination of the description of Eobowenia and the discovery of more serratemargined fossil Bowenia species and specimens makes this less likely.

The change in the Australian environment since the Eocene has been extreme and varied, and hence an explanation for the change in pinnule morphology and stomatal size and density is not straightforward (see this article). Since the Eocene, the Australian landmass has moved northward, and the photoperiod has altered dramatically, as has the angle of the sun in the sky during the growing period. There is also strong evidence that the Australian Eocene climate was relatively warm, with extremely high humidity throughout the year that dampened temperature extremes. Many of the fossil cuticles at the sites examined have high densities and diversities of epiphyllous fungi, which indicates extremely humid environments with no dry season (Lange 1976, 1978; Wells and Hill 1993). Furthermore, atmospheric $\mathrm{CO}_{2}$ levels during the Early Eocene were high by modern standards (Pagani et al. 2005; Lowenstein and Demicco 2006; Anagnostou et al. 2016), enhancing the global greenhouse effect as well as providing abundant $\mathrm{CO}_{2}$ for photosynthesis.

The small pinnules of B. eocenica and B. papillosa may have been advantageous in a warm climate, as small leaf size results in a thinner boundary layer (Yates et al. 2010), which enhances convective leaf cooling relative to large pinnules with thicker boundary layers. While this is well established for canopy trees, it is less well understood for understory plants, and Wright et al. (2017) concluded that in modern forests, the lower energy inputs in shaded situations may allow for relatively larger leaf sizes there. Hence the small, moderately serrate pinnules of $B$. eocenica and B. papillosa were unexpected, since both species occur among diverse angiosperm floras with relatively large leaf sizes, similar to those of extant tropical or subtropical rain forest. It is possible that the leaves of the fossilized species with small pinnules may have been tripinnate. Johnson (1959) noted that extant Bowenia has bipinnate leaves, but Wilson (2004) noted occasional tripinnate leaves in B. serrulata, and these leaves had significantly more and smaller pinnules per leaf than bipinnate leaves. There is a possible advantage in having tripinnate leaves for these understory cycads growing in complex rain forests in dense shade, at high latitudes, and where the sun is always low in the sky and coming from different directions near the horizon throughout the day. Small but numerous photosynthetic units may be a very effective way to maximize light uptake in such an environment where sunflecks are the major source of light (this article). Although no extant cycads from high latitudes are tripinnate, fossilized tripinnate cycads and ferns have been described (e.g., Artabe and Stevenson 1999; Carvalho et al. 2013). Bowenia johnsonii probably did not follow the same strategy as B. eocenica and B. papillosa. It has relatively large pinnules compared with the other fossil Bowenia species and hence was more likely to have had bipinnate leaves. The larger surface area of these pinnules may represent another strategy to maximize light uptake in the high-latitude, understory environment, a scenario that is consistent with the very low stomatal conductance associated with the small, low-density stomata. Also consistent with this idea is the fact that extant B. spectabilis, which grows in rain forest understories, has larger pinnules than $B$. serrulata, which typically occurs in more open environments.

Among the living species of Bowenia, serrations appear to increase in presence and size as the vegetation opens. Based on the extant species, and given the likely light environment when the Eocene forests were growing, entire-margined pinnules would have been predicted for the fossil taxa. However, all these taxa are serrate (figs. 2, 4; table 2). Many hypotheses have been proposed to explain the presence of serrate margins in leaves. With genera that have only simple dichotomous venation, it is possible that as photosynthetic area reduces in cooler and/or drier environments, the lamina shrinks back from the margin more quickly than the vein endings, and hence the individual vein endings become serrations. Given that extant B. spectabilis can be either entire-margined or minutely serrate, depending on the vegetation type it occurs in, this trait is clearly variable within the genus.

\section{Conclusion}

Bowenia is a particularly interesting genus that is far removed morphologically from other extant and fossil cycads, with the exception of Eobowenia. The fossil record of Bowenia is important in determining the past distribution of the genus, and also provides some insight into the evolution of the extant species, but as yet offers no information on the origins of the genus. It is likely that further Cretaceous finds of Bowenia and closely re- 
lated taxa will be required to answer more detailed questions about the evolution of this genus.

\section{Acknowledgments}

We thank the Queensland Herbarium (BRI), National Herbarium of Victoria (MEL), and Australian Tropical Herbarium (QRS) for providing specimens and the South Australian Her- barium (AD) and Melbourne Museum for fossil specimen loans. We also thank the Exploration Data Centre of the Geological Survey of Queensland for core samples, Dr. Mike Macphail for opinions on the palynology of key sites, and the Australian Research Council for the funding that made this research possible. We are especially grateful to Professor Sergio Archangelsky and Dr. L.C.A Martínez for providing images of the holotype of Eobowenia incrassata.

\section{Literature Cited}

Acuña-Castillo R, W Marín-Méndez 2013 Comparative anatomy of leaflets of Zamia acuminata and Z. pseudomonticola (Zamiaceae) in Costa Rica. Rev Biol Trop 61:539-546.

Anagnostou E, EH John, KM Edgar, GL Foster, A Ridgwell, GN Inglis, RD Pancost, DJ Lunt, PN Pearson 2016 Changing atmospheric $\mathrm{CO}_{2}$ concentration was the primary driver of early Cenozoic climate. Nature 533:380-384.

Archangelsy S 1966 New gymnosperms from the Ticó Flora, Santa Cruz Province, Argentina. Bull Br Mus (Nat Hist) 13:261-295.

Artabe AE, DW Stevenson 1999 Fossil Cycadales of Argentina. Bot Rev 65:219-238.

Barnes RW, RS Hill 1999 Macrofossils of Callicoma and Codia (Cunoniaceae) from Australian Cainozoic sediments. Aust Syst Bot 12: 647-670.

Basinger JF, DC Christophel 1985 Fossil flowers and leaves of the Ebenaceae from the Eocene of southern Australia. Can J Bot 63:1825-1843

Bigwood AJ, RS Hill 1985 Tertiary Araucarian macrofossils From Tasmania. Aust J Bot 33:645-656.

Blackburn DT 1981 Tertiary megafossil flora of Maslin Bay, South Australia: numerical taxonomic study of selected leaves. Alcheringa 5:9-28.

Bogler DJ, J Francisco-Ortega 2004 Molecular systematic studies in cycads: evidence from $\operatorname{trn} \mathrm{L}$ intron and ITS2 rDNA sequences. Bot Rev 70:260-273.

Cande SC, JM Stock, RD Müller, T Ishihara 2000 Cenozoic motion between East and West Antarctica. Nature 404:145-150.

Carpenter RJ, MP Goodwin, RS Hill, K Kanold 2011 Silcrete plant fossils from Lightning Ridge, New South Wales: new evidence for climate change and monsoon elements in the Australian Cenozoic. Aust J Bot 59:399-425.

Carpenter RJ, RS Hill, LJ Scriven 2006 Palmately lobed Proteaceae leaf fossils from the Middle Eocene of South Australia. Int J Plant Sci 167:1049-1060.

Carpenter RJ, GJ Jordan, RS Hill 2007 A toothed Lauraceae leaf from the Early Eocene of Tasmania, Australia. Int J Plant Sci 168:11911198.

2016 Fossil leaves of Banksia, Banksieae and pretenders: resolving the fossil genus Banksieaephyllum. Aust Syst Bot 29:126141.

Carpenter RJ, GJ Jordan, MK Macphail, RS Hill 2012 Near-tropical Early Eocene terrestrial temperatures at the Australo-Antarctic margin, western Tasmania. Geology 40:267-270.

Carpenter RJ, MK Macphail, GJ Jordan, RS Hill 2015 Fossil evidence for open, Proteaceae-dominated heathlands and fire in the Late Cretaceous of Australia. Am J Bot 102:2092-2107.

Carvalho MR, P Wilf, EJ Hermsen, MA Gandolfo, NR Cúneo, KR Johnson 2013 First record of Todea (Osmundaceae) in South America, from the early Eocene paleorainforests of Laguna del Hunco (Patagonia, Argentina). Am J Bot 100:1831-1848.

Chamberlain CJ 1912 Two species of Bowenia. Bot Gaz 54:419-423. Chaw SM, TW Walters, CC Chang, SH Hu, SH Chen 2005 A phylogeny of cycads (Cycadales) inferred from chloroplast matK gene,
trnK intron, and nuclear rDNA ITS region. Mol Phylogenet Evol 37:214-234.

Christophel DC 1980 Occurrence of Casuarina megafossils in the Tertiary of southeastern Australia. Aust J Bot 28:249-259.

- 1984 Early Tertiary Proteaceae: the first floral evidence for the Musgraveinae. Aust J Bot 32:177-186.

1989 Evolution of the Australian flora through the Tertiary. Plant Syst Evol 162:63-78.

1994 The early Tertiary macrofloras of continental Australia. Pages 262-275 in R Hill, ed. History of the Australian vegetation: Cretaceous to recent. Cambridge University Press, Cambridge.

Christophel DC, DT Blackburn 1978 Tertiary megafossil flora of Maslin Bay, South Australia: a preliminary report. Alcheringa 2:311319.

Christophel DC, WK Harris, AK Syber 1987 The Eocene flora of the Anglesea locality, Victoria. Alcheringa 11:303-323.

Christophel DC, SD Lys 1986 Mummified leaves of two new species of Myrtaceae from the Eocene of Victoria, Australia. Aust J Bot 34:649-662.

Coiro M, C Pott 2017 Eobowenia gen. nov. from the Early Cretaceous of Patagonia: indication for an early divergence of Bowenia? BMC Evol Biol 17:97.

Condamine FL, NS Nagalingum, CR Marshall, H Morlon 2015 Origin and diversification of living cycads: a cautionary tale on the impact of the branching process prior in Bayesian molecular dating. BMC Evol Biol 15:65.

Conran JG, RJ Carpenter, GJ Jordan 2009 Early Eocene Ripogonum (Liliales: Ripongonaceae) leaf macrofossils from southern Australia. Aust Syst Bot 22:219-228.

Foster CB, WK Harris 1981 Azolla capricornica sp. nov. First Tertiary record of Azolla Lamarck (Salviniaceae) in Australia. Trans R Soc S Aust 105:195-204.

Greenwood DR 1987 Early Tertiary Podocarpaceae: megafossils from the Eocene Anglesea Locality, Victoria, Australia. Aust J Bot 35:111-133.

1994 Palaeobotanical evidence for Tertiary climates. Pages 4459 in R Hill, ed. History of the Australian vegetation: Cretaceous to recent. Cambridge University Press, Cambridge.

Greguss P 1968 Xylotomy of the living cycads with a description of their leaves and epidermis. Akademiai Kiado, Budapest.

Hill KD 1998a Stangeriaceae. Pages 636-637 in AE Orchard, ed. Flora of Australia. Vol 48. Ferns, gymnosperms and allied groups. ABRS/CSIRO, Melbourne.

Hill KD, MW Chase, DW Stevenson, HG Hills, B Schutzman 2003 The families and genera of cycads: a molecular phylogenetic analysis of Cycadophyta based on nuclear and plastid DNA sequences. Int J Plant Sci 164:933-948.

Hill RS 1978 Two new species of Bowenia Hook, ex Hook, f. from the Eocene of eastern Australia. Aust J Bot 26:837-846.

1980 Three new Eocene cycads from eastern Australia. Aust J Bot 28:105-122.

1982 The Eocene megafossil flora of Nerriga, New South Wales, Australia. Palaeontogr Abt B 181:44-77. 
1986 Lauraceous leaves from the Eocene of Nerriga, New South Wales. Alcheringa 10:327-351.

1989 Early Tertiary leaves of the Menispermaceae from Nerriga, New South Wales. Alcheringa 13:37-44.

1990 Araucaria (Araucariaceae) species from Australian Tertiary sediments: a micromorphological study. Aust Syst Bot 3:203220.

$1998 b$ The fossil record of cycads in Australia. Pages 539-544 in AE Orchard, ed. Flora of Australia. Vol 48. Ferns, gymnosperms and allied groups. ABRS/CSIRO, Melbourne.

Hill RS, AJ Bigwood 1987 Tertiary gymnosperms from Tasmania: Araucariaceae. Alcheringa 11:325-335.

Hill RS, RJ Carpenter 1991 Evolution of Acmopyle and Dacrycarpus (Podocarpaceae) foliage as inferred from macrofossils in southeastern Australia. Aust Syst Bot 4:449-479.

Hill RS, DC Christophel 1988 Tertiary leaves of the tribe Banksieae (Proteaceae) from south-eastern Australia. Bot J Linn Soc 97:205-227. Hill RS, MS Pole 1992 Leaf and shoot morphology of extant Afrocarpus, Naegia, and Retrophyllum (Podocarpaceae) species, and species with similar leaf arrangement, from Tertiary sediments in Australasia. Aust Syst Bot 5:337-358.

Hill RS, LJ Scriven 1998 Falcatifolium (Podocarpaceae) macrofossils from Paleogene sediments in southeastern Australia: a reassessment. Aust Syst Bot 11:711-720.

Johnson LAS 1959 The families of cycads and the Zamiaceae of Australia. Proc Linn Soc N S W 84:64-117.

Lange RT 1976 Fossil epiphyllous "germlings", their living equivalents and their palaeohabitat indicator value. Neues Jahrb Geol Palaontol Abhandlungen 151:142-165.

1978 Southern Australian Tertiary epiphyllous fungi, modern equivalents in the Australasian region, and habitat indicator value. Can J Bot 56:532-541.

Lowenstein TK, RV Demicco 2006 Elevated Eocene atmospheric $\mathrm{CO}_{2}$ and its subsequent decline. Science 313:1928.

Macphail MK, RS Hill, RJ Carpenter, JL McKellar 2014 Cenozoic oil-shale deposits in southeastern-central Queensland: palynostratigraphic age determinations and correlations for the Biloela Formation (Biloela Basin) in GSQ Monto 5. Queensland Geological Record 2014/01.

McGowran B, WK Harris, JM Lindsay 1970 The Maslin Bay flora, South Australia. 1. Evidence for an early middle Eocene age. Neues Jahrb Geol Palaontol Monatshefte 8:481-485.

McLoughlin S, RJ Carpenter, GJ Jordan, RS Hill 2008 Seed ferns survived the end-Cretaceous mass extinction in Tasmania. Am J Bot 95:465-471.

Nagalingum NS, CR Marshall, TB Quental, HS Rai, DP Little, S Mathews 2011 Recent synchronous radiation of a living fossil. Science 334:769-799.

Noon T 1982 Stratigraphic drilling report-GSQ Monto 5. Queensl Government Mining J 83:450-456.

Pagani M, JC Zachos, KH Freeman, B Tipple, S Bohaty 2005 Marked decline in atmospheric carbon dioxide concentrations during the $\mathrm{Pa}$ leogene. Science 309:600-603.

Pant DD, DD Nautiyal 1963 Cuticle and epidermis of recent Cycadales. Leaves, sporangia and seeds. Senckenb Biol 44:257-347.

Passalia MG, G Del Fueyo, S Archangelsky 2010 An Early Cretaceous zamiaceous cycad of South West Gondwana: Restrepophyllum nov. gen. from Patagonia, Argentina. Rev Palaeobot Palynol 161:137150

Paull R, RS Hill 2009 Libocedrus macrofossils from Tasmania (Australia). Int J Plant Sci 170:381-399.

Pole MS 2007 Early Eocene dispersed cuticles and mangrove to rainforest vegetation at Strahan-Regatta Point, Tasmania. Palaeontol Electron 10:15A

Pole MS, MK Macphail 1996 Eocene Nypa from Regatta Point, Tasmania. Rev Palaeobot Palynol 92:55-67.
Rowett AJ 1988 The megafossil and microfossil floras of the Curlew Formation, Queensland. PhD diss. The University of Adelaide, Adelaide.

1998 One Tree Hill macrofossil flora. MESA J 9:21-23.

Rozefelds AC, DC Christophel, NF Alley 1992 Tertiary occurrence of the fern Lygodium (Schizaeaceae) in Australia and New Zealand. Mem Queensl Mus 32:203-222.

Rozefelds AC, ME Dettmann, HT Clifford, RJ Carpenter 2017 Lygodium (Schizaeaceae) in southern high latitudes during the Cenozoic: a new species and new insights into character evolution in the genus. Rev Palaeobot Palynol 247:40-52.

Salas-Leiva DE, AW Meerow, M Calonje, MP Griffith, J FranciscoOrtega, K Nakamura, DW Stevenson, CE Lewis, S Namoff 2013 Phylogeny of the cycads based on multiple single-copy nuclear genes: congruence of concatenated parsimony, likelihood and species tree inference methods. Ann Bot 112:1263-1278.

Sandiford M, M Quigley 2009 TOPO-OZ: insights into the various modes of intraplate deformation in the Australian continent. Tectonophysics 474:405-416.

Scriven LJ 1993 Diversity of the mid-Eocene Maslin Bay Flora, South Australia. PhD diss. The University of Adelaide, Adelaide, South Australia.

Scriven LJ, S McLoughlin, RS Hill 1995 Nothofagus plicata (Nothofagaceae), a new deciduous Eocene macrofossil species, from southern continental Australia. Rev Palaeobot Palynol 86:199-209.

Stevenson DW 1981 Observations on Ptyxis, phenology, and trichomes in the Cycadales and their systematic implications. Am J Bot 68:11041114.

1990 Chigua, a new genus in the Zamiaceae with comments on its biogeographic significance. Mem N Y Bot Gard 57:169172.

Stevenson DW, KJ Norstog, DV Molsen 1996 Midribs of cycad pinnae. Brittonia 48:67-74.

Thomas HH, N Bancroft 1913 On the cuticles of some recent and fossil cycadean fronds. Trans Linn Soc Lond 8:155-204.

Treutlein J, M Wink 2002 Molecular phylogeny of cycads inferred from rbcL sequences. Naturwissenschaften 89:221-225.

Truswell EM, JA Owen JA 1988 Eocene pollen from Bungonia, New South Wales. Mem Assoc Aust Palaeontol 5:259-284.

Uzunova K, E Palamarev, Z Kvacek 2001 Eostangeria ruzinciniana (Zamiaceae) from the Middle Miocene of Bulgaria and its relationship to similar taxa of fossil Eostangeria, and extant Chigua and Stangeria (Cycadales). Acta Palaeobot 41:177-193.

Webb LJ 1959 A physiognomic classification of Australian rain forests. J Ecol 47:551-570.

Wellman P, I McDougall 1974 Potassium-argon ages on the Cainozoic volcanic rocks of New South Wales. J Geol Soc Aust 21:247272.

Wells AK, RS Hill 1993 Epiphyllous microorganisms as palaeoclimate estimators: the developmental sequence of fungal "germlings" on their living host. Aust Syst Bot 6:377-386.

Wells PM, RS Hill 1989 Fossil imbricate-leaved Podocarpaceae from Tertiary sediments in Tasmania. Aust Syst Bot 2:387-423.

Wilson GW 2004 The biology and systematics of Bowenia Hook. ex Hook. f. (Stangeriaceae: Bowenioideae). MSc diss. James Cook University, Townsville, Queensland.

Wright IJ, N Dong, V Maire, IC Prentice, M Westoby, S Díaz, RV Gallagher, et al 2017 Global climate drivers of leaf size. Science 357:917-921.

Yates MJ, GA Verboom, AG Rebelo, MD Cramer 2010 Ecophysiological significance of leaf size variation in Proteaceae from the Cape Floristic Region. Funct Ecol 24:485-492.

Zgurski JM, HS Rai, QM Fai, DJ Bogler, J Francisco-Ortega, SW Graham 2008 How well do we understand the overall backbone of cycad phylogeny? new insights from a large, multigene plastid data set. Mol Phylogenet Evol 47:1232-1237. 